\title{
IN VITRO DIRECT AND INDIRECT PROPAGATION OF BLACKBERRY (RUBUS SP.)
}

\author{
Awatef M. Badr-Elden ${ }^{1}$, Ahmed A. Nower ${ }^{1}$, Adel A. Abdallah ${ }^{2}$ and Hind A. Albeah ${ }^{1}$ \\ ${ }^{1}$ Plant Biotechnology Department, Genetic Engineering and Biotechnology Research Institute, University of Sadat \\ City, Egypt \\ ${ }^{2}$ Environmental studies \& Research Institute, University of Sadat City, Egypt \\ Corresponding author, E-mail: ahmed.nower@gebri.usc.edu.eg
}

\begin{abstract}
In vitro direct and indirect propagation of blackberry (Rubus sp.) were studied. Blackberry explants are easily oxidized, so the uses of the running tap water for washing about one hour before sterilization allowed avoiding the oxidation. The disinfection process was represented using different concentrations of Clorox $(10,15,20 \%)$ with exposure times ( 5 and $10 \mathrm{~min}$.), the best treatment being achieved by the concentration of $(10 \%$ for $5 \mathrm{~min}$.) for shoot tips and $(5 \%$ for $5 \mathrm{~min})$ for leaves disinfectant. A normal growth and development occurred only in the BA of the multiplication, but at Kin or TDZ decreased in the shoots growth was induced. Maximum volume of callus induction and callus \% were produced at TDZ or 2mg/I NAA or 2,4$D$ each alone from leaf explants. Addition of $2.0 \mathrm{mg} / \mathrm{I} \mathrm{TDZ}$ into media increased the callus induction from in vitro leaves than ex vitro leaves and having the best response. The highest responses of organogenesis obtained from In-vitro leaves than ex vitro leaves. The increased rooting of shoots appeared when MS reduced to $1 / 2$ salts strength and produced highest leaves number, plant length $(\mathrm{cm})$ and roots number. While, MS reduced to $1 / 4$ salts strength resulted in tallest of roots $(2.72 \mathrm{~cm})$. The rooting of plants derived from $1 / 2 \mathrm{MS}$ salt strength medium give highest leaves number, plant length, roots number and roots length than other strengths of MS after two months from acclimatization in greenhouses.
\end{abstract}

Key words: Acclimatization, callus, in vitro, multiplication, organogenesis.

\section{INTRODUCTION}

Blackberry belongs to the Rosaceae family and is a shrubby tree with erect, semi erect or creep grown habit, and most cultivars have thorny stems. Propagation of blackberry by hardwood or stem cuttings has been poor and variable (Bray et al., 2003). Tip layering propagation requires a sizeable planting for the layering bed, few tips are available per plant. Softwood cuttings root readily, but require considerably more care for successful plant production (Broomrand Zimmerman, 1978). Successful application of these methods of vegetative propagation is limited to certain extent (Najaf-Abadi and Hamidoghli, 2009). Berry fruits are an economically important crop in many countries. Interest in berry fruits has recently increased because they are good sources of health -promoting vitamins, anti -oxidants and many nutrients (Song and Sing, 2004). Economical important of in vitro propagation has been recorded in great number of blackberry cultivars (Mengetal., 2004). Tissue culture is applied to many nursery crops including red raspberries and other Rubus species. Shoot culture, a form of plant tissue culture, is an important technique for uniform mass production (Mehlenbacher, 2008). In vitro culture becomes important because the increasing demand worldwide for these fruit. In recent years, in vitro multiplication becomes very important since the plant material obtained through this technique high quality and safety compared to the traditional method. Furthermore, this methodology will facilitate the multiplication of some plants with desirable agronomic traits that today are only found in small towns and have a great potential for research purposes and for small farms production (Jadan et al., 2015). These experiments were

Special volume for the first International Conference of Genetic Engineering and Biotechnology, 
carried out aiming to direct and in direct propagation, rooting and acclimatization of Blackberry.

\section{MATERIALS AND METHODS.}

This study was carried out during 2011-2015 at the Laboratory of Germplasm conservation and gene transfer. Stock plant materials were obtained from Genetic Engineering and Biotechnology Research Institute (GEBRI) farm, University of Sadat City Egypt.

Sterilization.

\section{Shoot tips and leaves sterilization}

Explants of Blackberry (Rubus sp.) were washed thoroughly under running tap water for one hour, then surface sterilized with commercial disinfectant Clorox $(5.25 \% \mathrm{NaOCl})$ solution using different concentration, 10, 15, $20 \%(\mathrm{v} / \mathrm{v})$ for (5 and 10 minutes with shoot tips) and (5, 10 and 15 minutes with leaves) followed by rinsing three times with sterile distilled water to remove traces of Clorox then $0.1 \%(\mathrm{~m} / \mathrm{v})$ mercuric chloride for 5 minutes followed by rinsing three times with sterile distilled water to remove traces of mercuric chloride under a laminar airflow cabinet then inoculated in freegrowth regulators MS salt medium (Murashige and Skoog, 1962) supplemented with $3 \%$ sucrose and $7 \mathrm{~g} / \mathrm{l}$ agar, $\mathrm{pH}$ was adjusted at 5.7. All cultures were kept at a temperature of $25 \pm 2{ }^{\circ} \mathrm{C}$ under $16 \mathrm{~h}$ photoperiod at 3000 lux light intensity. Sterilization had been detected as disinfectant of explants.

Multiplication. The shoots resulting after the initiation phase were passed to the multiplication phase. Shoots were multiplied on MS medium supplemented with $0,0.5,1,1.5$ and $2 \mathrm{mg} / \mathrm{l}$ 6benzylaminopurine ((BA), (Kin) Kinetin or Thidiazuron (N-phenyl- $\mathrm{N}^{0}$-1,2,3-thiadiazol-5yl-urea (TDZ) each alone. The cultures were kept in a growth chamber at $25 \pm 2^{\circ} \mathrm{C}$, with 16 hours photoperiod and 3000 lux of light intensity. Data were recorded after 6 weeks as shoots number, leaves number and shoots length $(\mathrm{cm})$.
Callus induction.

Effect of Auxins (IBA, NAA and 2,4-D) and cytokinins (BA and TDZ) on callus induction of blackberry.

For callus induction from in vitro and ex vitro leaves were cultured on MS medium supplemented with different concentration of IBA, NAA and 2,4-D $(0.0,0.5,1.0$ and $2.0 \mathrm{mg} / \mathrm{l})$ and combination with $2 \mathrm{mg} / \mathrm{I} \mathrm{BA}$ or TDZ. Data were taken after 6 weeks as explants able to induction of callus $\%$ and volume of callus according to the method described by (Pottino, 1981) as follows:

Negative results (-) 1 Below average results (+) 2

Good results (+++) $4 \quad$ Very good result (++++) 5.

Effect of TDZ at different concentrations on callus induction and differentiation

The experiment was carried out to compare the effect of the different concentration of TDZ on the in vitro and ex vitro leaves on callus induction. Young, fully expanded leaves from upper thirds of in vitro propagated shoots were used as initial explants and the same from the (ex vitro leaves after sterilization) were cultured on MS medium contained 0.0, 1.0, 1.5, 2.0 and $2.5 \mathrm{mg} / \mathrm{l}$ TDZ. Data were recorded after 6 weeks. Callus formation was estimated as explants able to induction of callus\% and differentiation of shoots from callus.

Rooting. Shoots were obtained from multiplication used for in vitro rooting. Explants were cultured on different strengths of MS medium (full, $3 / 4,1 / 2$ and $1 / 4$ ) supplemented with $2 \mathrm{mg} / \mathrm{l}$ indole-3-butyric acid (IBA), 30g/l sucrose. Data were recorded after six weeks as a number of roots, root length $(\mathrm{cm})$, number of leaves and plant length $(\mathrm{cm})$.

Acclimatization. Plants excessed from rooting were transferred to plastic pots $(6 \mathrm{~cm})$ containing a mixture of sterilized peat moss and perlite (1:1) and covered with lids. The plantlets were gradually exposed to normal greenhouse conditions. Survival of plants is recorded as roots number, roots length $(\mathrm{cm})$, leaves number and plant length $(\mathrm{cm})$ after two months.

Statistical analyses. The randomized factorial design was used and data were subjected to analysis of variance. Separation of means among 
treatments was determined using LSD test at 5\% (Steel and Torrie, 1980).

\section{RESULTS AND DISCUSSION}

Effect of Clorox at different concentrations and exposure time on disinfection of shoots tips and leaves sterilization.

Table (1) and fig. (1) showed that disinfectant concentrations on contamination, indicate that, using colorox at $15 \%$ gave the highest survival of disinfectant (14.67), with no significantly different between other treatments. Concerning the main effect of sterilization time, shoot tips remain in disinfectant with colorox at $5 \mathrm{~min}$ gave high survival of disinfectant appearance (14.33) than $10 \mathrm{~min}$. Data of interaction indicated that, maximum explant were appearance clean (17.67) by using Clorox at $10 \%$ for $5 \mathrm{~min}$ than other treatments.

The effect of clorox concentrations and exposure times on disinfectant and sterilization of leaves were tested (Table 2) and (Fig. 2). Maximum disinfectant of leaves obtained at a concentration $10 \%$ of Clorox than other concentrations of clorox. Concerning the main effect of sterilization time,
Blackberry explants are easily oxidized, so the uses of the running tap water for explants washing for one hour before sterilization allowed avoiding the oxidation. The effects of Clorox concentrations and sterilization time on disinfection of shoot tips were studied.

leaves remain in disinfectant at $5 \mathrm{~min}$ than 10 and 15 min. Data of interaction indicated that, the highest explant were appearance clean by using clorox at $5 \%$ for 5 and $10 \mathrm{~min}$ ( 19.00 and 19.33, respectively) than other treatments. These results lead to concede the best treatment for blackberry shoot tips sterilization is using clorox at $5 \%$ for 5 and 10 min. considering both contamination appearance and appearance clean. While, using clorox at $15 \%$ for $5 \mathrm{~min}$ best treatment for blackberry leaves disinfectant. From our results showed that contamination and viability of the explants depend on the concentration of Clorox used. Isac et al., 2014 found that the shoots were surface sterilized in $70 \%$ ethanol for 10 minutes followed by $20 \mathrm{~min}$. in sodium hypochlorite ( $2 \%$ available chlorine) were successful and contaminants were infrequent.

Table (1): Effect of Clorox at different concentrations and exposure time on disinfection of shoots tips.

\begin{tabular}{|c|c|c|c|c|}
\hline \multirow{2}{*}{\multicolumn{2}{|c|}{$\begin{array}{c}\text { Clorox } \\
\text { Concentration \% }\end{array}$}} & \multicolumn{3}{|c|}{ Disinfection time (min) } \\
\hline & & 5 & 10 & Mean \\
\hline \multicolumn{2}{|c|}{10} & 10.33 & 16.67 & 13.5 \\
\hline \multicolumn{2}{|c|}{15} & 17.67 & 11.67 & 14.67 \\
\hline \multicolumn{2}{|c|}{20} & 15.00 & 11.67 & 13.35 \\
\hline \multicolumn{2}{|c|}{ Mean } & 14.33 & 13.67 & \\
\hline \multirow[t]{3}{*}{ L S D at $5 \%$} & A & \multicolumn{3}{|c|}{2.213} \\
\hline & B & \multicolumn{3}{|c|}{1.807} \\
\hline & $A \times B$ & \multicolumn{3}{|c|}{3.129} \\
\hline
\end{tabular}

Special volume for the first International Conference of Genetic Engineering and Biotechnology, 


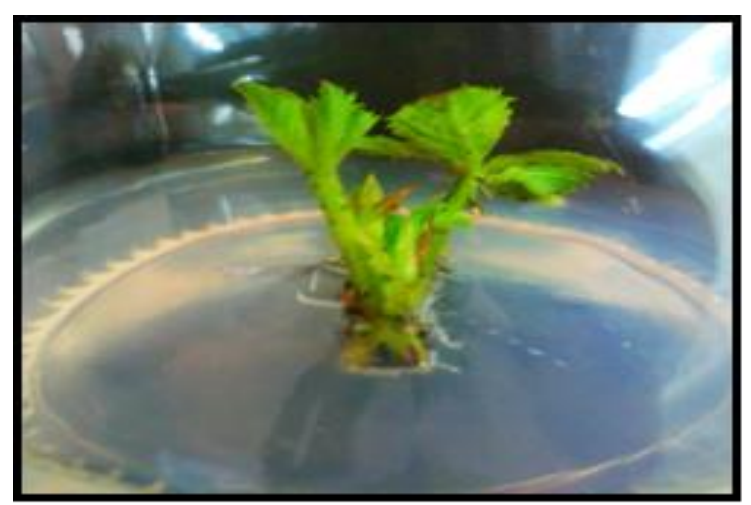

Fig(1):Sterilization and development of shoot tips.

Table (2): Effect of Clorox at different concentrations and exposure time on disinfection of leaves.

\begin{tabular}{|c|c|c|c|c|}
\hline \multirow{2}{*}{$\begin{array}{c}\text { Clorox } \\
\text { concentration \% }\end{array}$} & \multicolumn{4}{|c|}{ Disinfection time (min) } \\
\hline & 5 & 10 & 15 & Means \\
\hline 10 & 19.33 & 19.00 & 17.33 & 18.56 \\
\hline 15 & 16.33 & 13.33 & 11.33 & 13.67 \\
\hline 20 & 15.33 & 12.33 & 10.67 & 12.78 \\
\hline Mean & 17.00 & 14.89 & 13.11 & \\
\hline L S D at $5 \%$ & \multicolumn{4}{|c|}{0.8844} \\
\hline B & \multicolumn{4}{|c|}{0.8844} \\
\hline$A \times B$ & \multicolumn{4}{|c|}{1.532} \\
\hline
\end{tabular}

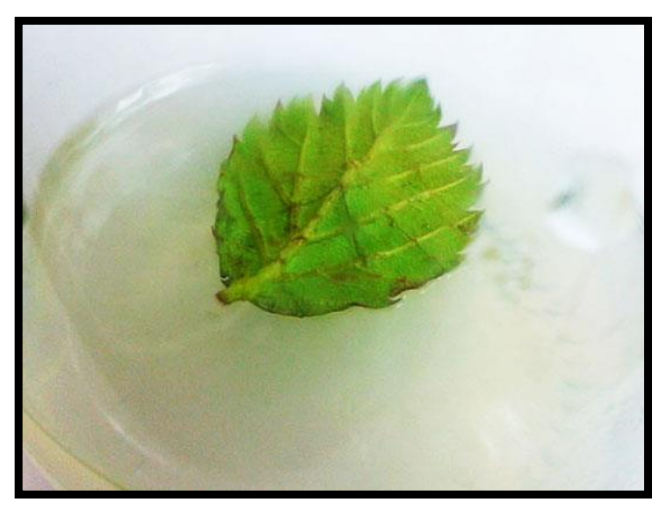

Fig (2): Sterilization of leaf

Effect of cytokinins (BA, Kin and TDZ) and concentration on growth and development of blackberry in vitro.

In vitro multiplication of plants the use of cytokinins in the multiplication medium is very important, this hormone enhancing cell division and in vitro proliferation of shoot tips. Irrespective of the culture media used, BA produced maximum of shoots than Kin or TDZ. Even at low doses of BA, Kin or TDZ medium amount of shoots was induced, while doses such as $1.5 \mathrm{mg} / \mathrm{l}$ BA generated high

Special volume for the first International Conference of Genetic Engineering and Biotechnology, 
shoots formation than other treatments as shown in Table (3) and Fig. (3). Using the BA increased the leaves number than Kin or TDZ. Explants cultured on MS medium supplemented with $1.0 \mathrm{mg} / \mathrm{IBA}$ showed evident faster growth of the leaves number. The leaves were grew less vigorous at 0.5 or $2.0 \mathrm{mg} / \mathrm{I} \mathrm{Kin}$ than other treatments. The multiplication stage was characterized by an approximate six weeks of shoot formation. A normal development occurred only in the BA of the multiplication cycle, but at Kin or TDZ decreased in the shoots growth was induced. Our results are agree with those, Isac et al., 2014 found that cytokinins like BAP is very effective in promoting direct or indirect shoot initiation of blackberry. Fira et al., 2014 reported that the optimal cytokinin proved to be BAP at $0.5 \mathrm{mg} / \mathrm{l}$ concentration for cultivars 'Chester Thornless' and 'Loch Ness', 0.3 mg/l for 'Navaho' of blackberry. Debnath 2014 reported that shoot elongation was best in a medium containing $4.4 \mu \mathrm{M}$ of 6 benzyladenine (BA) for rasberry. Amalia et al., 2014 found that $(B A)$ resulted the highest shoot initiation rate in three cultivars of rasberry. The increased number of internodes and higher plants were achieved using the concentrations of $2 \mathrm{mg} / \mathrm{l}$ BAP (Jadán et al., 2015).

Table (3): Effect of cytokinins BA, Kin and TDZ on growth and development of blackberry.

\begin{tabular}{|c|c|c|c|c|c|c|}
\hline \multirow{3}{*}{$\begin{array}{l}\text { Cytokinin } \\
\text { type }\end{array}$} & \multicolumn{6}{|c|}{ Shoots number } \\
\hline & \multicolumn{6}{|c|}{ Cytokinin con. mg/l } \\
\hline & 0.0 & 0.5 & 1.0 & 1.5 & 2.00 & Means \\
\hline BA & 4.00 & 7.00 & 13.60 & 15.00 & 14.00 & 10.73 \\
\hline Kin & 4.00 & 3.80 & 4.40 & 3.80 & 4.20 & 4.04 \\
\hline TDZ & 4.00 & 4.40 & 4.00 & 3.80 & 3.40 & 3.92 \\
\hline Means & 4.00 & 5.06 & 7.33 & 7.53 & 7.20 & \\
\hline \multirow[t]{2}{*}{ L S D at $5 \% A$} & \multicolumn{6}{|c|}{1.041} \\
\hline & \multicolumn{6}{|c|}{1.345} \\
\hline B & \multicolumn{6}{|c|}{2.329} \\
\hline \multicolumn{7}{|l|}{$A \times B$} \\
\hline \multicolumn{7}{|c|}{ Leaves no. } \\
\hline & 0.0 & 0.5 & 1.0 & 1.5 & 2.00 & Means \\
\hline BA & 25.60 & 21.60 & 28.00 & 23.00 & 22.20 & 24.08 \\
\hline Kin & 25.60 & 21.20 & 18.00 & 22.60 & 15.60 & 20.60 \\
\hline TDZ & 25.60 & 16.40 & 25.60 & 18.20 & 23.00 & 21.76 \\
\hline Means & 25.60 & 19.73 & 23.86 & 21.26 & 20.26 & \\
\hline L S D at $5 \% A$ & \multicolumn{6}{|c|}{3.113} \\
\hline & \multicolumn{6}{|c|}{4.019} \\
\hline B & \multicolumn{6}{|c|}{6.962} \\
\hline \multicolumn{7}{|l|}{$A \times B$} \\
\hline \multicolumn{7}{|c|}{ Shoot length $(\mathrm{cm})$} \\
\hline & 0.0 & 0.5 & 1.0 & 1.5 & 2.00 & Means \\
\hline BA & 4.40 & 3.40 & 3.18 & 2.70 & 2.60 & 3.26 \\
\hline Kin & 4.40 & 5.06 & 4.70 & 5.17 & 4.43 & 4.75 \\
\hline TDZ & 4.40 & 3.93 & 4.00 & 4.59 & 4.20 & 4.22 \\
\hline Means & 4.40 & 4.13 & 3.96 & 4.15 & 3.76 & \\
\hline L S D at $5 \% \mathrm{~A}$ & \multicolumn{6}{|c|}{0.4466} \\
\hline & \multicolumn{6}{|c|}{0.5766} \\
\hline B & \multicolumn{6}{|c|}{0.9987} \\
\hline AxB & & & & & & \\
\hline
\end{tabular}

Special volume for the first International Conference of Genetic Engineering and Biotechnology, 


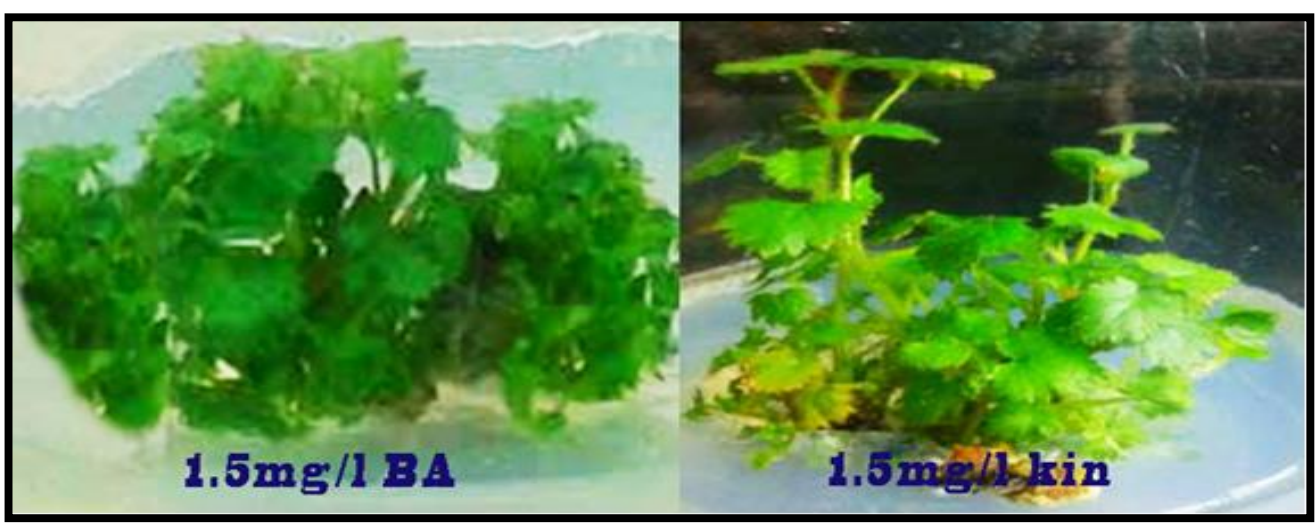

Fig. (3): Development and proliferation of blackberry shoots on MS medium and 1.5mg/I BA.

Effect of Auxins (IBA, NAA and 2,4-D) and cytokinins ( $B A$ and TDZ) on callus induction of blackberry.

Callus was initiated mainly in media with (IBA, NAA and 2,4-D) combination with BA or TDZ. Callus initiation from leaves was observed at various concentrations of (IBA, NAA and 2,4-D) at 0.5,1.0 and $2.0 \mathrm{mg} / \mathrm{L}$. Optimum concentrations of 2,4-D for callus induction $\%$ and volume of callus was observed with $2 \mathrm{mg} / \mathrm{L}$ (Fig. 4). The addition of cytokinin, TDZ to the culture media containing different (IBA, NAA and 2,4-D) levels stimulate greatest callus induction $\%$ and volume of callus than BA as shown in Table (4). The use of the TDZ alone or $2 \mathrm{mg} / \mathrm{I}$ NAA or 2,4-D each alone were effective in initiating callus $\%$ and volume of callus from leaf explants. TDZ is a high promoted to caulogenesis in the leaves than other treatments in this study. The best callus medium for induction of raspberry cell suspension appeared to be the one supplemented with 2,4,D (1.0 mg/l) (Dziadczyk, et al., 2013). The highest callus induction of strawberry (90\%) was produced with anther in medium contained 2,4,D (2.0 mg/I) + IAA (1.0 mg/l) + BA(0.4 mg/l) (Nguyen, et al.,2015).
Table (4): Effect of Auxins concentrations (IBA, IAA and NAA) and (BA or TDZ) on callus formation of blackberry leaves.

\begin{tabular}{|c|c|c|c|c|c|c|c|}
\hline \multirow{3}{*}{$\begin{array}{l}\text { Auxins } \\
\text { types }\end{array}$} & \multirow{3}{*}{$\begin{array}{l}\text { Conc. } \\
\text { (mg/l) }\end{array}$} & \multicolumn{6}{|c|}{ Callus formation } \\
\hline & & \multicolumn{3}{|c|}{ Volume } & \multicolumn{3}{|c|}{ Percentage } \\
\hline & & BA & TDZ & Means & BA & TDZ & Means \\
\hline \multirow{4}{*}{ IBA } & 0 & 1.25 & 3.5 & 2.37 & 16.25 & 70 & 43.12 \\
\hline & 0.5 & 2.5 & 2.00 & 2.25 & 45.00 & 42.5 & 43.75 \\
\hline & 1.0 & 1.25 & 2.25 & 1.75 & 12.50 & 30.25 & 21.37 \\
\hline & 2.0 & 1.5 & 2.25 & 1.87 & 21.25 & 38.75 & 30.00 \\
\hline \multirow{4}{*}{ NAA } & 0 & 1.25 & 3.5 & 2.37 & 16.25 & 70.00 & 43.12 \\
\hline & 0.5 & 1.75 & 1.75 & 1.75 & 28.75 & 30.00 & 29.37 \\
\hline & 1.0 & 2.75 & 2.5 & 2.62 & 54.00 & 51.25 & 52.62 \\
\hline & 2.0 & 1.25 & 3.75 & 2.12 & 15.5 & 59.75 & 37.62 \\
\hline \multirow{4}{*}{ 2,4-D } & 0 & 1.25 & 3.5 & 2.37 & 16.25 & 70.00 & 42.00 \\
\hline & 0.5 & 1.75 & 2.25 & 2.00 & 27.5 & 42.5 & 35.00 \\
\hline & 1.0 & 2 & 2.25 & 2.12 & 31.25 & 32.5 & 31.87 \\
\hline & 2.0 & 3.25 & 3.25 & 3.25 & 71.5 & 62.5 & 67.00 \\
\hline \multicolumn{2}{|l|}{ Means } & 1.83 & 2.64 & & 29.47 & 50.00 & \\
\hline \multirow[t]{3}{*}{ LSD at $5 \%$} & A & \multicolumn{3}{|c|}{0.8064} & \multicolumn{3}{|c|}{21.59} \\
\hline & B & \multicolumn{3}{|c|}{0.3292} & \multicolumn{3}{|c|}{8.814} \\
\hline & $\mathrm{AB}$ & \multicolumn{3}{|c|}{1.140} & \\
\hline
\end{tabular}

Effect of TDZ concentration on callus induction and differentiation callus from leaves in-vitro and exvitro of blackberry.

The callus induction from in vitro and ex vitro leaves of blackberry can be easily achieved by using different concentrations of TDZ. Callus volume and callus $\%$ were increased by using TDZ at $(2 \mathrm{mg} / \mathrm{l})$ than other treatments as shown in Table (5). Maximum volume of callus produced and callud \% were obtained from in vitro leaves (3.0) than ex vitro leaves (1.40). Addition of 1.5 and $2.0 \mathrm{mg} / \mathrm{I} \mathrm{TDZ}$ into media increases the amount of formed calli from in vitro leaves than ex vitro leaves. Using TDZ did not reduce the callus amount while increased the callus formation (Fig. 5). Such influence of concentrations of TDZ on caulogenesis was also observed in other reporters (Vescan, et al., 2012) reported that for callus of blackberry the one produced on T2 0.2

Special volume for the first International Conference of Genetic Engineering and Biotechnology, 


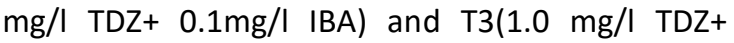
$0.1 \mathrm{mg} / \mathrm{I}$ IBA) media showed the best general condition, these media being recommended for further experiments. Debnath, $\mathbf{2 0 1 4}$ found that leaf of rasberry produced larger callus with increasing levels of TDZ up to $9.0 \mu \mathrm{M}$. TDZ is its often-inhibitory effects on shoot elongation. Yucesan et al., 2015 reported that low concentrations of TDZ have been found to be using for proliferation of Gooseberry, whereas higher concentrations induce callus in woody plants.

Differentiation or (Organogenesis from callus): Table (5) and

Fig. (5) maximum callus differentiation and organogenesis formation (2.70) in MS medium supplemented with TDZ at $2.0 \mathrm{mg} \backslash \mathrm{I}$ than other concentrations. Also the highest responses of differentiation to produced shoots from callus and differentiation \% obtained from in vitro leaves (2.12) than ex vitro leaves (1.97). TDZ was significantly more effective to inducing adventitious organogenesis from in vitro leaves at $2 \mathrm{mg} / \mathrm{l}$ than other treatments. Adding TDZ into regeneration medium formation of callus mass of light green. The results indicate that the addition of TDZ to the culture medium, acts positively on the regeneration from callus. Results obtained for best concentration of TDZ are similar to those obtained in other studies. Lazić and Ružić 2007 found that the highest regeneration from callus was obtained on medium supplemented with TDZ alone (41.66\%) of blackberry leaves. Husaini and Abdin 2007 reported that shoot organogenesis is best when leaf explants are cultured on lower concentration of TDZ $(9.08 \mu \mathrm{M})$, whereas somatic embryogenesis is best when leaf explants are cultured on relatively higher concentration of TDZ $(18.16 \mu \mathrm{M})$ of strawberry.

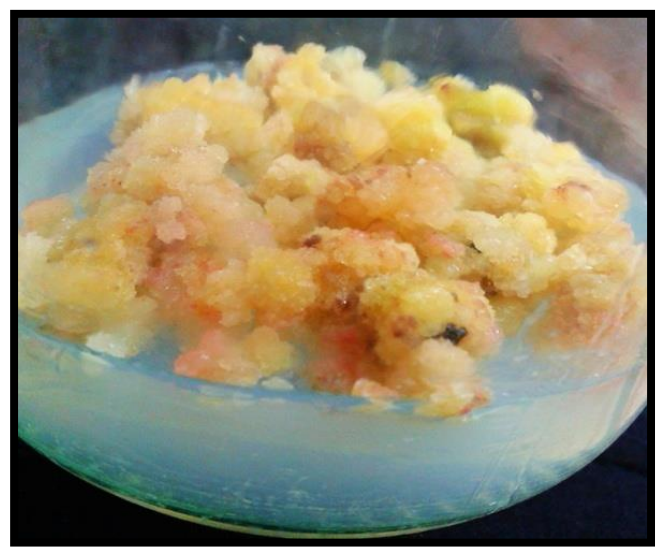

Fig (4); Callus induction from in vitro leavers 
Table (5): Effect of TDZ concentration on callus induction and differentiation callus from leaves in vitro and ex vitro of blackberry.

\begin{tabular}{|c|c|c|c|c|c|c|c|c|c|c|c|c|}
\hline \multirow{3}{*}{$\begin{array}{l}\text { TDZ conc. } \\
\text { (mg) }\end{array}$} & \multicolumn{6}{|c|}{ Callus formation } & \multicolumn{6}{|c|}{ Differentiation of callus } \\
\hline & \multicolumn{3}{|c|}{ Volume of callus / leaf } & \multicolumn{3}{|c|}{ Callus \% } & \multicolumn{3}{|c|}{$\begin{array}{c}\text { No. of shoot /callus/ } \\
\text { leaf }\end{array}$} & \multicolumn{3}{|c|}{ Differentiation \% } \\
\hline & $\begin{array}{l}\text { Ex- } \\
\text { vitro }\end{array}$ & $\begin{array}{l}\text { In- } \\
\text { vitro }\end{array}$ & Means & $\begin{array}{l}\text { Ex- } \\
\text { vitro }\end{array}$ & $\begin{array}{l}\text { In- } \\
\text { vitro }\end{array}$ & Means & $\begin{array}{l}\text { Ex- } \\
\text { vitro }\end{array}$ & $\begin{array}{l}\text { In- } \\
\text { vitro }\end{array}$ & Means & $\begin{array}{c}\text { Ex- } \\
\text { vitro }\end{array}$ & $\begin{array}{l}\text { In- } \\
\text { vitro }\end{array}$ & Means \\
\hline Control & 1 & 1 & 1.00 & 10.00 & 11.66 & 10.83 & 0.01 & 0.01 & 0.01 & 13.33 & 16.66 & 15.00 \\
\hline $1.0 \mathrm{TDZ}$ & 1 & 3 & 2.00 & 6.66 & 58.33 & 32.50 & 0.46 & 1.40 & 0.93 & 17.00 & 22.00 & 19.50 \\
\hline $1.5 \mathrm{TDZ}$ & 2 & 3 & 2.50 & 20.00 & 68.33 & 44.17 & 0.46 & 2.60 & 1.53 & 21.00 & 63.33 & 42.16 \\
\hline $2.0 \mathrm{TDZ}$ & 2 & 4 & 3.00 & 25.00 & 80.00 & 52.50 & 0.80 & 4.60 & 2.70 & 20.00 & 86.66 & 53.33 \\
\hline $2.5 \mathrm{TDZ}$ & 1 & 4 & 2.50 & 8.33 & 83.33 & 45.83 & 1.20 & 2.00 & 1.60 & 17.83 & 47.16 & 32.83 \\
\hline Means & 1.40 & 3.00 & & 13.99 & 60.33 & & 1.97 & 2.12 & & 17.83 & 47.16 & \\
\hline $\begin{array}{r}\text { LSD at } 5 \% \text { A } \\
B \\
A B\end{array}$ & & $\begin{array}{l}0.543 \\
0.859 \\
1.215\end{array}$ & & & $\begin{array}{c}5.76 \\
9.11 \\
12.90\end{array}$ & & 1.257 & $\begin{array}{l}0.562 \\
0.888\end{array}$ & 0.5 & & $\begin{array}{l}4.66 \\
6.60 \\
9.33\end{array}$ & \\
\hline
\end{tabular}

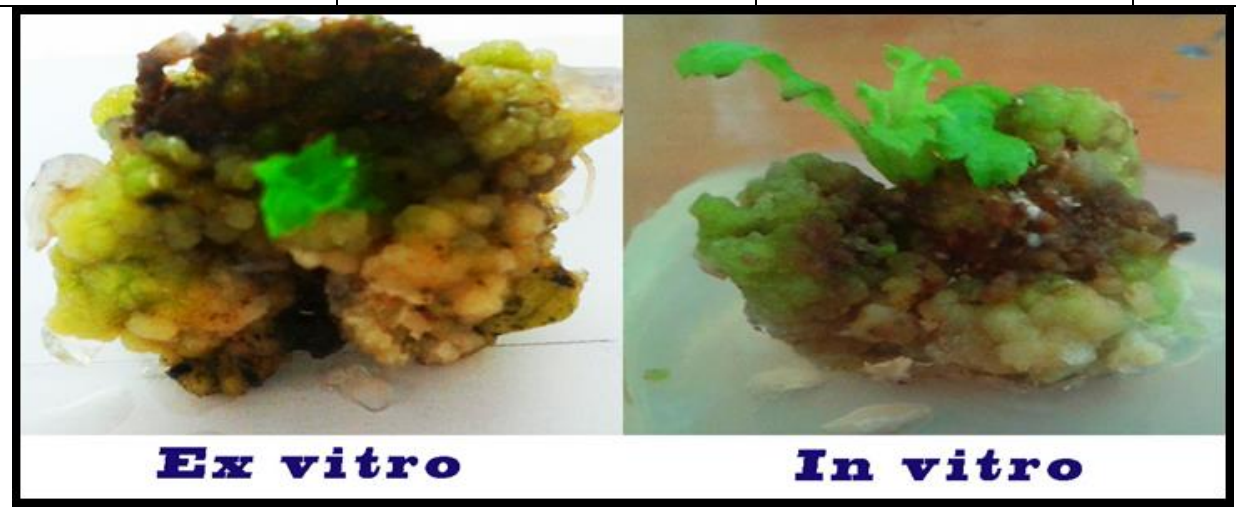

Fig. (5): Development of organogenesis from $1.5 \mathrm{mg} / \mathrm{TDZ}$ on ex vitro and in vitro leaves of blackberry in vitro.

Effect of MS salt strengths on in vitro rooting and adaptation in greenhouse of blackberry.

The success of root formation from Blackberry (Rubus sp.) explants lead to study more factors that may affect in vitro growth of Blackberry (Rubus sp.). Nutrient salt strength is possessed to be important factor affecting in vitro growth. In this study MS medium were used with different strengths $(1,3 / 4,1 / 2$, $1 / 4 \mathrm{MS}$ ). At rooting of shoots indicated that the MS reduced to $1 / 2$ mineral salts was produced highest, leaves number, plant length $(\mathrm{cm})$ and roots number. While, MS reduced to $1 / 4$ mineral salts resulted in tallest of roots $(2.722 \mathrm{~cm}$ ) Table (6) and Fig. (6).

Special volume for the first International Conference of Genetic Engineering and Biotechnology, 
Table (6): Effect of MS salt strengths on in vitro rooting of blackberry.

\begin{tabular}{|l|l|l|l|l|}
\hline $\begin{array}{l}\text { MS salt strengths } \\
(\mathrm{g})\end{array}$ & Leaves no. & Plant length $(\mathrm{cm})$ & Roots no. & $\begin{array}{l}\text { Roots length } \\
(\mathrm{cm})\end{array}$ \\
\hline Full & $4.230 \mathrm{~B}$ & $3.646 \mathrm{~B}$ & $0.9320 \mathrm{C}$ & $0.7500 \mathrm{~B}$ \\
\hline $3 / 4$ & $6.730 \mathrm{AB}$ & $6.074 \mathrm{~A}$ & $5.160 \mathrm{AB}$ & $1.882 \mathrm{AB}$ \\
\hline $1 / 2$ & $8.090 \mathrm{~A}$ & $6.444 \mathrm{~A}$ & $5.970 \mathrm{~A}$ & $2.280 \mathrm{AB}$ \\
\hline $1 / 4$ & $4.224 \mathrm{~B}$ & $4.434 \mathrm{~B}$ & $3.680 \mathrm{~B}$ & $2.722 \mathrm{~A}$ \\
\hline LSD at 5\% & $\mathbf{2 . 5 7 5}$ & $\mathbf{1 . 5 1 2}$ & $\mathbf{2 . 2 2 6}$ & $\mathbf{1 . 5 5 8}$ \\
\hline
\end{tabular}

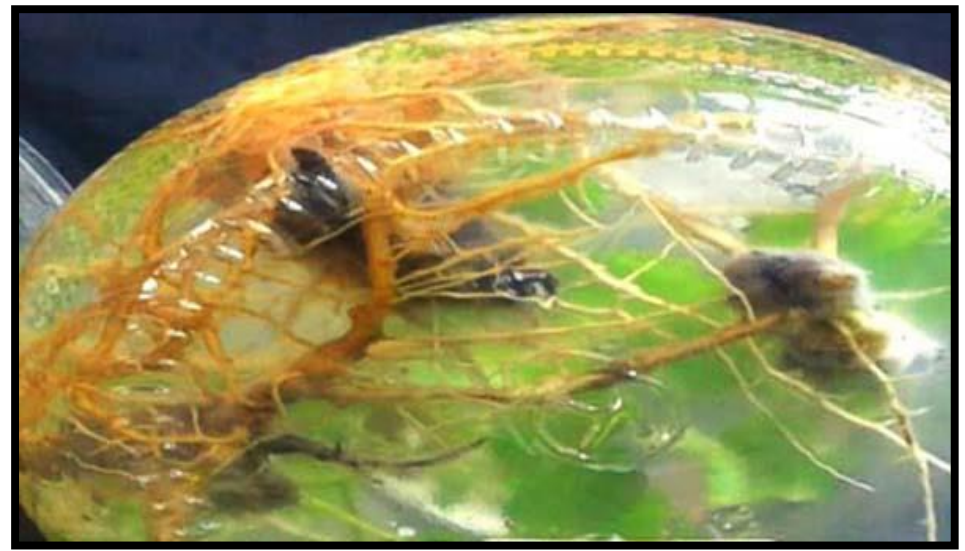

Fig. (6): Development of rooting on $1 / 2$ MS medium .

This result agrees with a number of published papers on rooting of blackberry (Ruzic et al., (2009). In vitro rooting from raspberries reveals that the MS medium with half the minerals and supplemented with auxin is essential for the strengthening of rooting (Isac, 2009). Karim, et al., 2015 reported that $86 \%$ of the shoots of strawberry were induced to develop root in $1 / 2 \mathrm{MS}$ rooting medium without PGR. The rooted of strawberry were gradually acclimatized and transferred to the ex vitro condition for field evaluation. 25\% MS strength medium without NAA gave the highest percentage of rooted shoots and greatest number of primary and secondary roots (Ceretta et al., 2000).
At the acclimatization, the results proved that the survival of blackberry plantlets at acclimatization stage was highly affected by MS salt strengths that affected on root formation at rooting stage. The produced highest leaves number, plant length, roots number and roots length were obviously obtained with plantlets derived from rooting $1 / 2 \mathrm{MS}$ medium than other strengths of MS media Table (7) and Fig.(7). This result was in accordance with those obtained by Badr-Elden et al., 2012 reported that, maximum rooted shoots of watermelon produced on half strength MS medium $0.5 \mathrm{mgL}^{-1}$ IBA were transferred to pots and acclimatized in green-house with a survival rate of $80 \%$. Muhsen et al., 2013 found that $0.5 \mathrm{~g} / \mathrm{L}^{-1} \mathrm{NPK}$ and half strength of

Special volume for the first International Conference of Genetic Engineering and Biotechnology, 
Hoagland solution increase the acclimatized of Date Palm plantlets $80 \%$, and increasing leave chlorophyll content of the date palm. Bhandari et al., $\mathbf{2 0 1 3}$ reported that maximum roots of plantlets when transferred to $1 / 4 \mathrm{MS}$ strength medium having
3\% sucrose devoid of PGR for seven days and transferred to polybags containing a mixture of soil: sand: FYM manure (1:1:1) and kept for two weeks in mist-chamber under controlled condition (temp. $25^{\circ} \mathrm{C} \pm 2{ }^{\circ} \mathrm{C}$ ), humidity $65 \% \pm 5 \%$.

Table (7): Effect of in vitro MS salt strengths on growth and development of blackberry in greenhouses after two months.

\begin{tabular}{|c|l|c|c|c|c|}
\hline $\begin{array}{c}\text { MS salt } \\
\text { strengths (g) }\end{array}$ & Leaves no. & Plant length $\mathbf{( c m )}$ & Root no. & Root length $(\mathbf{c m})$ & Survival \% \\
\hline Full & 7.66 & 5.00 & 8.600 & 4.66 & 63.33 \\
\hline $3 / 4$ & 9.33 & 7.33 & 9.300 & 7.00 & 66.67 \\
\hline $1 / 2$ & 14.33 & 10.00 & 11.100 & 8.67 & 98.33 \\
\hline $1 / 4$ & $\mathbf{6 . 6 6}$ & $\mathbf{8 . 3 3}$ & 8.400 & 6.00 & 76.67 \\
\hline LSD at 5 \% & $\mathbf{0 . 5 9 8 7}$ & $\mathbf{1 . 1 1 1}$ & $\mathbf{1 . 7 1 8}$ & $\mathbf{1 . 1 1 1}$ & $\mathbf{7 . 4 8 8}$ \\
\hline
\end{tabular}

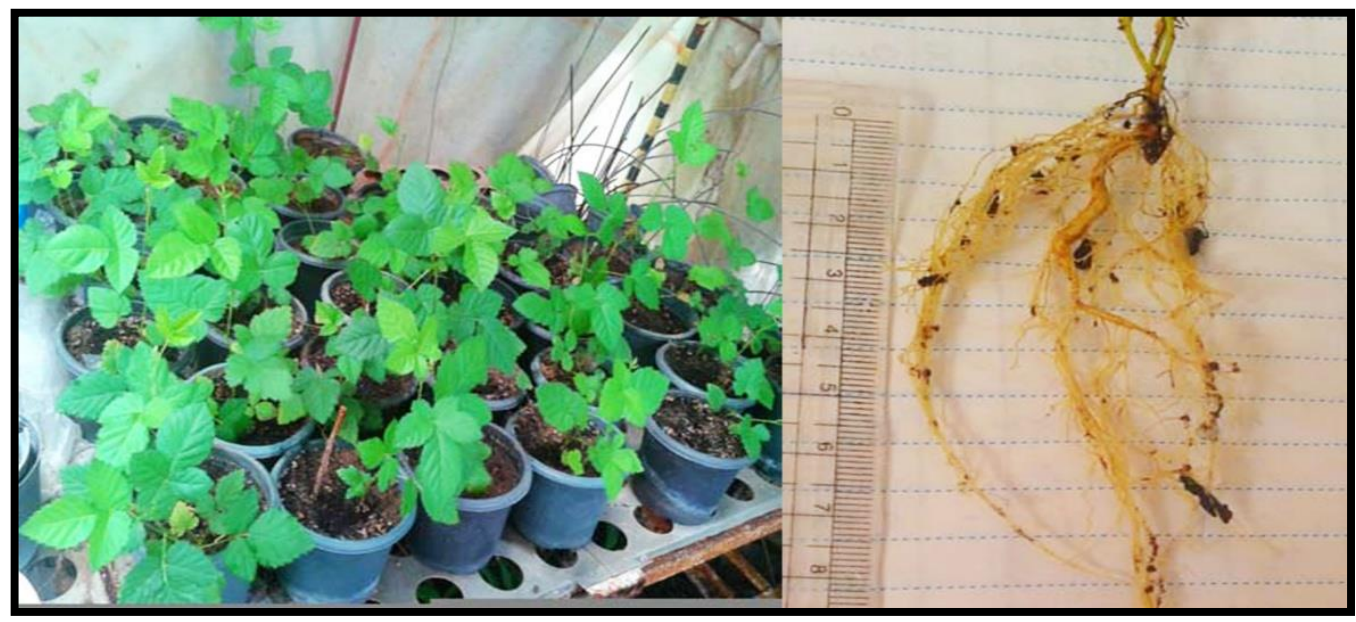

Fig. (7): Adaptation of blackberry plants derived from in vitro $1 / 2 \mathrm{MS}$ rooting medium in greenhouse

\section{REFERENCES}

Amalia,F.; Debanth,S.C. and Yeoung,Y.R.(2014). Effects of calcium gluconate and ascorbic acid on controlling shoot necrosis during micropropagation of primocane- fruiting raspberry (Rubus ideaeus L. ) cultivars. African Journal of Biotecnology. Vol.13(47):4361-4368.

Badr-Elden A. M.; Ahmed A. Nower; Ibrahim A. Ibrahim; Mohsen K.H. Ebrahim and Tamer M. Abd Elaziem (2012): Minimizing the hyperhydricity associated with in vitro growth and development of watermelon by modifying the culture conditions. African Journal of Biotechnology Vol. 11(35), pp. 8705-8717

Bhandari, A.; Baunthiyal, M.; Bisht, V.K.; Singh,N. and Negi, J.S. (2013): A quick bud breaking response of a surface model for rapid clonal propagation in Centella asiatica (L.).International Journal for Biotechnology and Molecular Biology Research, 4 (6): 9397.

Special volume for the first International Conference of Genetic Engineering and Biotechnology, 
Bray, M.M., C.R. Rom, and J.R. Clark. (2003). Propagation of thornless Arkansas blackberries by hardwood cuttings. Discovery (Univ. of Arkansas) 4:9-13.

Broomr,O.C. and Zimmerman, R.H. (1978).In vitro propagation of blackberry. HortScience, Vol(2): 151- 153

Ceretta, M., Coutinho, E.F., Fortes, G.R.de L.Dantas, A.C. de M. (2000):In vitro rooting of blackberry (Rubus sp.) cultivar Caingangue. Agropecuaria Clima Temperado. Vol. 3 No.2 pp. 123-130.

Debnath, S.C. (2009)2014 . A two-step procedure for adventitious shoot regeneration on excised leaves of low bush blueberry. In Vitro Cell.Dev.Biol.-Plant. Vol.(45):122128.

Dziadczyk, E.; Domaciuk, M., Dziadczyk, P., Pawelec, I., Szczuka, E. and Bednara, J. (2013). Optimization on in vitro culture condition influencing the initiation of raspberry (Rubus idaeus L. cv. Nawojka ) cell suspension culture. Versita. Vol.LXVIII:(2)15-24.

Fira,A. ;Clapa,D. and Simu,M. (2014). Studies regarding the micropagation of some Blackberry cultivars. Bulletin U.A.S.V.M. Hortculture,Vol.71(1)29-35.

Husaini,A.M. and Abdin, M.Z.(2007): Interactive effect of light, temperature and TDZ on the regeneration potential of leaf discs of Fragaria $x$ ananassa Duch. In Vitro Cell.Dev.Biol. Vol.43:576-584.

Isac, V. 2009. Procotol for in vitro micropropagation of raspberry, and plant regeneration by organogénesis. In: Mezzetti, B.; Ružić, D. and Gajdosova, A. (Eds.). A guide to some in vitro techniques. Small fruits. European research: from genomics to sustainable production, quality and health. 14-23 pp.

Isac,V., C. Plopa and C. Nicola 2014: Propagation of new blackberry cultivars for producing certified propagation material. Fruit Growing Research, Vol.X, 66-71.
Jadán, M., Ruiz, J. , Soria, N. , mihai, R.A. 2015. Synthetic seeds production and the induction of organogenesis in blackberry (Rubus glaucus Benth) . Romanian Biotechnological Letters Vol. 20, No. 1, 1034-1042.

Karim,R.; Ahmed,F.; Krishna Roy,U.; Islam,R. and Hossain,M.(2015). Varietal improvement of Strawberry (Fragaria $x$ ananassa Dutch.) through somaclonal variation using In vitro techniques. J. Agr. Sci. Tech. Vol.17:977-986.

Lazić T. and Đ. Ružić (2007): Organogenesis in vitro from the leaf of blackberry $\mathrm{cv}$ Čačanska bestrna. - Genetika, Vol. 39, No. 1, 69- 78.

Mehlenbacher, S.A., 2008. Genetic resources for hazelnut: State of the art and future perspectives. Acta Hortic. 845, 33-38.

Meng R, Chen THH, Finn CE, Li J (2004) Improving in vitro plant regeneration from leaf and petiole explants of 'Marion' blackberry. HortScience 39(2): 316-320.

Muhsen,K.A.; Jasim, A.M. and Abbas, K.I. (2013): Effect Of NPK and Hoagland solution on acclimatization of Date Palm plantlets Phoenix Dactylifera L cv. Barhee produced in vitro. Basra Science Journal, 39(4): 32 45.

Murashige, T. and Skoog, F. (1962).A revised medium for rapid growth and bioassays with tobacco tissue culture. Physiol. Plant, Vol. (15): 473-497.

Nguyen, T.X. ; Song, Y. and Park, S. (2015). Androgenesis induction through anther culture in day-neutral strawberry (Fragaria $x$ Ananassa Duch) cv. " Everest ". J. Sci. \& Devel. Vol.13( 2):279-290.

Najaf-Abadi, A. J. and Hamidoghli,Y. (2009).Micropropagation of thornless trailing blackberry (Rubus sp.) by axillary bud explants. Australian Journal of Crop Science, Vol. (4): 191-194.

Pedrotti,E.L. and Voltolini,J.A.(2001).Ex vitro rooting and acclimatization M.9 apple 
rootstock. Rev. Bras. Frutic.,Jaboticabal-sp. Vol.(23):234-239.

Pottino, B.G. (1981). Methods in plant tissue culture. Dep.of Hort. Agric. College, Maryland Univ, Collage Park, Maryland USA pp. 8-29.

Ruzic, D.; Vujovic, T. and Cerovic,R. (2009). Protocols for in vitro micropagation for Blackberry and Black currant. Programme and Abstracts for COST863 Workshop 'The new biotechnology applied in berry fruits'.

Song Q., Sing K.C. 2004. Agrobacterium tumefaciens-mediated transformation ofblueberry (Vacciniumcorymbosum L.). Plant Cell Reports 23: 475-

Steel, R.G.D. and J.H. Torrie (1980). Principles and procedures of statistics, a biometrical approach. Second Edition. McGraw-Hill Book Co., New York, NY, pp 137-177.

Vescan,L.; Clapa,D., Fira,A. and Pamfil,D.(2012). Micropropagation of cold resistant blackberry cultivar ' Gazda'. Bulletin USAMV Animal Sciences and Biotechnologies. Vol.(69):1-2.

Yucesan,B.B.; Mohammed,A.; Arslan,M. and Gurel,E.(2015).Clonal propagation and synthetic seed production from nodal segments of Cape gooseberry (Physalisperuviana L.), a tropical fruit plant.Turkish Journal of Agriculture and Forestry. Vol.(39):1-10.

Special volume for the first International Conference of Genetic Engineering and Biotechnology, 